\title{
FIDE and ICCA Cooperation Agreement
}

The 1981 FIDE General Assembly approved the following agreement between FIDE and ICCA at its recent Atlanta meeting. The agreement will become effective upon approval by the ICCA membership. A ballot is enclosed for that purpose. Please return your ballots before January 1, 1982.

\section{Arreenenc bermeen $P, I, D, Z_{2}$ and $T, C, G, \Lambda$,}

The Uorld Chene Foderacton (F.I.D.E.) and the Incernaclonnl Compucer Chese Assoctactua (I.C.C.A.) declare thelr coaviction that a close collaboracton in the rom incerese of developient and promotion of chese is uneful.

Tor chat purpose, F.I.D.I. and I.C.C.A. Join as partaera in an aseoc1ac1on In wasch each parcoer revalas legally, econoalcally, and rechnically indopeodent.

The bueloese of F.I.D.E. and of I.C.C.A. Wll be governed by the auchortt1es in che Y.I.D.E. and I.C.C.A. scacuces, respectively.

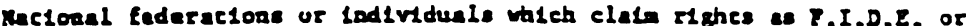
I.C.C.A. Dembers shall pay foes orly to the orgealiacloos of wich they are nembers.

F.I.D.S. and I.C.C.A. afflrm theis dealro to suide cheir aceivity and decisloan oo that the incerasts of nelcher partaor are violeced in developaus of ovur-che-board chese or compucar chese.

I.C.C.A. recognlzes P.I.D.Z. we the eupreae orgentzac1on of world chess

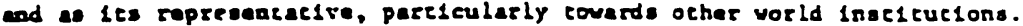
This recopielon shall noe preclude I.C.C.A. relacions co ocher vorld

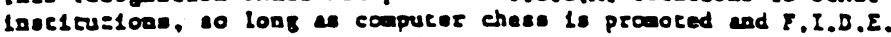
lecerescs are aot adrersely affaced.

F.I.D.P. recogalzes I.C.C.A. w the orly offletal lacemactonal federacton fur compucer chews courmanes ad cheploaships and for the necesany orgenisaction work.

Ondinar llatson mit becmee F.I.D.R. and I.C.C.A. shall be handled by the liatson officer elected by boch organizaclons (Delezace of P.I.D.E. for Cospucar Chess, reap. I.C.C.A. coneace person to P.I.D.E.). F.I.J.E. and I.C.C.A. hould afree sa che sere person as llalson officer.

Tor dlecussion of polley probless which concers boch partners, or of conElices becneen the partners, e comon P.I.D.Z./I.C.C.A. Cownlasion shall be eseablished. Thls comlesion shall conelse of two represereacives - lecrar by the I.C.C.A.. two elucted by the F.I.D.L. Congreas, and the 11.1son orflcer.

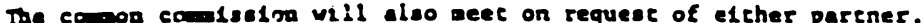
Meetinge wi: be called by the llatum offleer. The coundasion shall elect one of tits sembers as lis president.

I.C.C.A. should, if poesble, wee before che P.I.D.E. General Assentlles, se chac the I.C.C.A. alnuces an be added to the alnuces of che F.I.D.Z. General Aasembly.

Couputer chess e1Eles conferred by I.C.C.A. WIIl be ratifled by F.I.D.E. at the General Ansenblies, on the basis of qualification condicturs eneabll whed by I.C.C.A. and FIDE.

Nothing in this agreewent is locended to linte the powers or activities of tha ener federats one of IDDE.

This agrecenent thall contirue In force unc1l teriinated. The agreement ay be carninaced by elther partener at the ead of ay year, by writecen soctce to the ocher not lacer than october 31.

This agreemene shall becore effective upon approval by che P.I.D.E. Gens:al Aasembly and the I.S.C.A. Mebershlp. 